\section{COWDRY'S PROBLEMS OF AGEING}

Edited by A. I. Lansing, Ph.D. Third edition. Pp. xxiv + 1061 with 215 illustrations. London: Ballière, Tindall \& Cox, I952. I I4s.

This is an invaluable reference book on the changes that occur during ageing. The book includes sections on social and economic problems of ageing and on vital statistics, as well as clinical, histological and biochemical studies. Each system is dealt with in turn and there is a summary at the end of each chapter. An excellent bibliography is provided. Gerontology is becoming, in our ageing population, a subject of increasing importance and this is its principal textbook. It contains a mass of information not readily available elsewhere and can be unhesitatingly recommended.

\section{THE PRINCIPLES AND PRACTICE OF MEDICINE}

By L. S. P. Davidson, B.A., M.D., F.R.C.P. Pp. $\mathrm{xi}+919$ with 57 illustrations. Edinburgh: E. \& S. Livingstone Ltd., 1952. 32s. 6d.

A new textbook of medicine (" for students and doctors') is always something of an event and invites the question as to why it was written. The answer in Professor Davidson's new book is given at the beginning of the preface; 20 years ago he decided to cure the undergraduates of the habit of taking copious longhand notes of his, and his department's, lectures by providing cyclostyled notes. At first digests, these had grown until at last a textbook was the only answer to the annual production of many copies of 335 pages of foolscap! As such this book is written by a number of men, each an expert in his own field, and over it all, the welding and guiding influence of Professor Davidson is felt.

The style is clear, if dogmatic. Each section commences with a brief but practical refresher course in anatomy and physiology, followed by a more detailed and eminently sensible account of the methods of examination of the particular system. The main clinical conditions are then described, together with their treatments, with an approach which is delightfully realistic; the authors are to be congratulated upon the way in which they have shaken off so many of the heirlooms which generation after generation of textbook writers have not dared to discard.

The whole effect is that this book is a clear presentation of the modern concepts of medicine and one which students will find of great value as a systematic presentation of the main causes of sickness. It is open to the criticism that it does little to encourage the student to think for himself, but such is inevitable when the book's origins are recalled.

$$
\text { G.S.C.S. }
$$

\section{BIOCHEMISTRY AND HUMAN} METABOLISM

By B. S. Walker, M.D., Ph.D., W. C. Boyd, Ph.D., and I. Asimov, Ph.D. Pp. viii +812 , with $2 \mathrm{r}$ illustrations. London: Baillière, Tindall and Cox. 1952. 68s. 6d.

This book is intended primarily for medical students. It deals almost exclusively, therefore, with human biochemistry, and stresses its clinical applications.

The amount of up-to-date information it contains is remarkable, and where this is concerned with pure biochemistry it is accurate and well presented. The opening chapters on proteins, for instance, are excellent. The authors would do well, however, to avoid unnecessary excursions into clinical medicine, such as the statement on p. 512, that spontaneous hypoglycaemia 'is likely to occur in conscientious persons who are hyper-reactive to everyday frustrations.'

As a storehouse of information this book should prove valuable. As a guide to the classic names and landmarks of biochemistry it is misleading, since the references quoted seldom date from before 1945 and the vast majority occur in American journals. This policy is stated in the preface, it is true, but it can hardly be excused thereby. To the reviewer a chapter on oxygen transport and acid-base equilibrium which omits the names of Barcroft and Van Slyke betrays a lack of historical sense, as does a section on tissue oxidation which makes no mention of Meyerhof, Eimbden, Parnas, D. M. Needham or Keilin. The medical student may find information and instruction in this book, but not education nor a historical understanding of the subject.

P.H.S.

\section{HUMAN ACTINOMYCOSIS}

By V. Z. Cope, M.S., F.R.C.S. Pp. xii +80 , with 38 illustrations, 6 in colour. London: William Heinemann. 1952. 12s. $6 \mathrm{~d}$.

The aim of this book is to present the known facts about human actinomycosis to the general practitioner in an easily assimilable form.

Since the advent of penicillin, further progress in preventing the distressing late effects of this condition can only come from earlier diagnosis. To achieve this, practitioners must be constantly aware of the possibility of the presence of this condition, which may so often be mistaken for some other more common disease, until the pus is examined.

The author has succeeded in his purpose and the reader who takes up this book is assured of an interesting and friendly review of actinomycosis, made possible by the author's unique experience and life long interest in the subject, and by his flair for easy presentation.

M.S.B. 